\title{
Pesquisa brasileira no Congresso da American Thoracic Society
}

Neste número do J ornal de Pneumologia estão publicados os resumos de pesquisadores brasileiros que foram apresentados no Congresso Anual da American Thoracic Society (ATS), realizado em abril passado em San Diego, nos Estados U nidos da América(1).

Este é, sem dúvida, o melhor congresso de Pneumologia e áreas correlatas, onde são apresentados e discutidos os temas de maior interesse dos especialistas, as descobertas, os avanços, as controvérsias. É o grande palco das idéias novas, do renascimento dos conceitos antigos, das discussões sobre os erros e os acertos de uma especialidade que cresce acentuadamente e que faz valer sua importância no mundo moderno. É um congresso para clínicos, cirurgiões, pesquisadores básicos, endoscopistas, radiologistas, imunologistas, enfermeiros, fisioterapeutas, nutricionistas, etc. A tende aos interesses dos mais novos aos mais experientes. Enfim, qualquer pessoa que goste do pulmão tem o que aprender no congresso da ATS.

A publicação destes resumos foi autorizada pela ATS através do editor do American J ournal of Respiratory and Critical Care Medicine, Dr. Alan R. Leff, que compreendeu nossa intenção de divulgar no Brasil as pesquisas dos brasileiros. Esperamos com isso manter nossos leitores informados sobre o estado atual da pesquisa em nossa área no país. Desejamos, também, homenagear os indivíduos que com determinação vencem todas as dificuldades de realizar pesquisa no Brasil e conseguem ter seus trabalhos aceitos para apresentação no congresso da ATS.

Pretendemos manter esta realização do J ornal de Pneumologia anualmente. Q ueremos oferecer continuidade à informação dos leitores e queremos também, em alguns anos, ter um bom registro da atuação dos nossos pesquisadores na ATS.

Este número foi planejado com a divisão dos resumos por subespecialidades, respeitandose as áreas das Comissões Científicas da SBPT. Não houve trabalhos do âmbito das Comissões de Câncer Pulmonar, Micoses, Tabagismo, Epidemiologia e Circulação Pulmonar. Para os presidentes das demais Comissões foi solicitado que tecessem comentários sobre os trabalhos de suas respectivas áreas. Todo o material recebido foi compilado junto aos resumos e os leitores terão a oportunidade de ter, além dos resumos, uma visão geral e crítica sobre cada assunto.

Finalmente, solicito aos leitores que continuem enviando as Cartas ao Editor, com críticas, elogios, opiniões, sugestões. Certamente, o debate público das idéias nos tornará mais democráticos.

Thais Helena A. Thomaz Queluz

Editora

\section{REFERÊNCIA}

1. Abstracts. 1999 American Thoracic Society International Conference. Am J Resp Crit Care Med 1999;159(part 2):A 13A 991. 